\title{
Embryo deformities and nesting trends in Kemp's ridley sea turtles Lepidochelys kempii before and after the Deepwater Horizon oil spill
}

\author{
Donna J. Shaver ${ }^{1, *}$, Christian Gredzens ${ }^{1}$, J. Shelby Walker ${ }^{1}$, \\ Céline A. J. Godard-Codding ${ }^{2}$, Janet E. Yacabucci ${ }^{2}$, Amy Frey ${ }^{3}$, Peter H. Dutton ${ }^{3}$, \\ Christopher J. Schmitt ${ }^{4}$
}

\author{
${ }^{1}$ National Park Service, Padre Island National Seashore, Corpus Christi, TX 78480, USA \\ ${ }^{2}$ The Institute of Environmental and Human Health, Texas Tech University, Lubbock, TX 79409, USA \\ ${ }^{3}$ NOAA Fisheries, Southwest Fisheries Science Center, La Jolla, CA 92037, USA \\ ${ }^{4}$ US Geological Survey, Columbia Environmental Research Center, Columbia, MO 65201, USA
}

\begin{abstract}
Kemp's ridley sea turtles Lepidochelys kempii were disproportionately affected by the Deepwater Horizon (DWH) oil spill, which began on 20 April 2010. Embryo deformities were documented in inviable L. kempii eggs before (2008-2010) and after (2011-2013) the DWH spill in 2 Texas (USA) nesting areas (Upper Texas Coast and Padre Island National Seashore). Additional nesting trends, including clutch size and hatching success, were also investigated. Total and late-stage embryo deformity prevalence were 1.5 times greater after 2010 than before, but low in all nesting seasons (mean \pm SD: $0.7 \pm 8.5 \%$ total; $0.6 \pm 8.0 \%$ late-stage) and did not differ between locations. Craniofacial and carapace deformities were the most frequently observed deformity types. Documented nests in both areas declined in 2010 relative to previous years, ending an exponential increase observed beginning in 1995. Clutch size remained consistent before and after the spill. Hatching success averaged $87.0 \pm 33.3 \%$ in all years, but no effects from DWH were determined. Collectively, these data represent useful benchmarks against which to judge impacts of future crude oil spills and other catastrophic events.
\end{abstract}

KEY WORDS: Maternal exposure $\cdot$ Nest success $\cdot$ Craniofacial deformities $\cdot$ Gulf of Mexico $\cdot$ Texas

\section{INTRODUCTION}

On 20 April 2010, the Deepwater Horizon/Mississippi Canyon 252 (DWH) explosion and subsequent $87 \mathrm{~d}$ oil leak released $3.19 \times 10^{6}$ barrels $\left(5.07 \times 10^{8} 1\right)$ of oil into the northern Gulf of Mexico (GOM), resulting in the largest marine oil spill in history (DWH NRDA Trustees 2016). At its maximum extent, oil covered $112115 \mathrm{~km}^{2}$ of the GOM and ultimately contaminated the coasts of Louisiana, Mississippi, Alabama, and northern Florida (USA), including adjacent marine waters and wetlands (https://response.restoration.noaa.gov/erma). Crude oil released into the marine environment has

${ }^{*}$ Corresponding author: donna_shaver@nps.gov grave acute and chronic impacts on many taxa (Peterson et al. 2003), affecting growth rates, reproductive output, and overall fitness of individuals, as well as potentially impacting population dynamics. DWH oil directly and indirectly killed large numbers of organisms and contaminated important foraging and developmental habitats used by many species (Antonio et al. 2011, Henkel et al. 2012, White et al. 2012, Rozas et al. 2014, McDonald et al. 2017). Large amounts of fossil carbon from oil and gas released by the spill have been incorporated into the GOM ecosystem (Mitra et al. 2012, Cherrier et al. 2014, Quintana-Rizzo et al. 2015, Bonisoli-Alquati et al. 2016, Wilson et al. 2016,

(C) C.A.J. Godard-Codding, J.E. Yacabucci and outside the USA, the US Government 2021. Open Access under Creative Commons by Attribution Licence. Use, distribution and reproduction are unrestricted. Authors and original publication must be credited.

Publisher: Inter-Research · www.int-res.com 
Reich et al. 2017). The northern GOM, which experienced the heaviest impacts, provides key foraging habitat for adult female Kemp's ridley sea turtles Lepidochelys kempii that nest along the Texas and Mexico coasts (Seney \& Landry 2008, Shaver et al. 2013, Gredzens \& Shaver 2020).

L. kempii is predominantly a GOM species that is federally listed (endangered) in the USA (NMFS 2011), Critically Endangered globally (Wibbels \& Bevan 2019), and has the smallest geographic nesting range of all marine turtles (Pritchard \& MárquezMillán 1973). Nesting occurs primarily on western GOM beaches, in Tamaulipas and Veracruz, Mexico, and along the Texas coast (Pritchard \& MárquezMillán 1973) with limited nesting on other GOM and US Atlantic beaches (Shaver et al. 2016b). The majority of post-nesting $L$. kempii migrate northeastward along the GOM coast and forage in a shallow $(<37 \mathrm{~m}$ depth; Shaver \& Rubio 2008, Shaver et al. 2016a) coastal corridor from Texas to southwestern Florida, with strong foraging area fidelity (Seney \& Landry 2008, Shaver et al. 2013, 2016a, Gredzens \& Shaver 2020).

Adult L. kempii occur almost exclusively in the GOM, although subadults can inhabit the northwestern Atlantic Ocean along the US Atlantic coast (Lazell 1980, Morreale \& Standora 2005). Posthatchlings and smaller juveniles behave planktonically, congregating in convergence zones with other floating objects, including oil (McDonald et al. 2017). Effects of oil on L. kempii are a major concern to all life stages, including nesting females, and most of the turtles killed directly by DWH oiling were juvenile L. kempii (McDonald et al. 2017). Direct observation and post-spill modeling of the oil trajectory indicated that many $L$. kempii were exposed (Putman et al. 2015, Wallace et al. 2017). Additionally, $51.5 \%(\mathrm{n}=17)$ of adult female L. kempii, the majority of which were documented foraging in the northern GOM, showed isotopic signatures indicating oil exposure (Reich et al. 2017). Shortly after DWH exposure, marine turtle mortality rates increased exponentially (Antonio et al. 2011) and marine turtle nest densities decreased significantly on beaches near the spill area (e.g. northern GOM, loggerhead turtles Caretta caretta; Lauritsen et al. 2017).

Turtles that survived the initial and acute impacts of the spill may have sustained permanent or temporary physiological injury, experienced difficulty finding food, ingested or inhaled oil, consumed oil-contaminated prey, or moved to other foraging areas (e.g. Milton et al. 2010, Moreno et al. 2013, Beyer et al.
2016). Furthermore, oil exposure in reproductive female turtles can lead to maternal transfer of the lipophilic components of oil and their associated metabolites to eggs, causing embryo deformities and death (Fritts \& McGehee 1982, Van Meter et al. 2006, Shigenaka 2010, Field et al. 2017, Zychowski \& Godard-Codding 2017). While L. kempii rarely experience complete developmental failure of clutches (Backof et al. 2019), oil and related components can have other deleterious effects on turtle nests. In $C$. caretta, crude oil experimentally added to sand above incubating eggs led to significant embryonic mortality and morphological changes (Fritts \& McGehee 1982), while crude oil and oil-dispersant (Corexit) exposure led to clinicopathological abnormalities and failure to gain weight in hatchlings (Harms et al. 2019). Similarly, snapping turtle Chelydra serpentina eggs exhibited increased embryonic mortality and deformities following exposure to crude oil or oil components in vitro (Van Meter et al. 2006) and in situ, as did painted turtle eggs Chrysemys picta (Bell et al. 2006).

This study investigated potential spill effects on embryo deformities, clutch size, and nest success in L. kempii based on statistical comparisons and quantification of data from Texas nesting seasons before (2008-2010) and after (2011-2013) the DWH spill. Research findings on nesting $L$. kempii in Texas are important to the entire nesting population because all individuals constitute 1 genetic stock and a single regional management unit (Wallace et al. 2010). This study was part of the US Department of the Interior Natural Resource Damage Assessment of DWH effects on marine turtles, and serves as a basis for future investigations to prepare for, and respond to, damages caused by future oil spills. Additional information on other aspects of the investigation are described elsewhere (Hooper \& Schmitt 2015, Shaver et al. 2016a, Reich et al. 2017).

\section{MATERIALS AND METHODS}

\subsection{Study area}

The study area consisted of Kemp's ridley Lepidochelys kempii nesting beaches along 2 portions of the Texas coast where long-term monitoring has been conducted: the $105 \mathrm{~km}$ length of Padre Island National Seashore (PAIS) and a $100 \mathrm{~km}$ section on the Upper Texas Coast (UTC) extending from the southern terminus of Surfside Beach at Brazos Inlet northeastward the length of Bolivar Peninsula to 
Rollover Pass (Fig. 1). These areas accounted for $56.5 \%$ of US L. kempii nests during the study years, 2008-2013 (Shaver et al. 2016b). Systematic patrols were conducted each year to identify, document, and protect $L$. kempii nests. Nests discovered at PAIS and on the UTC were excavated and packed into polystyrene boxes containing sand from the nest sites, then transported to the PAIS laboratory facility for protected incubation, following protection protocols for most nests found on the Texas coast (Shaver \& Caillouet 2015). Incubated nests were categorized as those found at PAIS (PAIS-I) and those from the UTC for analyses. Eggs from some nests found at the southern end of PAIS were incubated in fenced beach corrals (PAIS-C). All hatchlings were released to the GOM at PAIS.

\subsection{Data collection}

Nesting females observed by biologists were examined for flipper tags and tagged with a passive integrated transponder (PIT) and 2 metal tags, if not already present. A biopsy sample was also collected from the trailing edge of one of the rear flippers, if possible, for genetic analyses. Each turtle was measured for maximum straight, maximum curved $(\mathrm{cm}$; nuchal notch to posterior tip; $\mathrm{SCL}_{n-t}, \mathrm{CCL}_{\mathrm{n}-\mathrm{t}}$ ), and/or minimum straight carapace length $(\mathrm{cm}$; nuchal notch to posterior notch; $\mathrm{SCL}_{n-n}$ ) at the first observation of the turtle in the study area each season. Conversion equations to determine $\mathrm{SCL}_{n-\mathrm{t}}$ from $\mathrm{CCL}_{n-\mathrm{t}}$ and $\mathrm{SCL}_{\mathrm{n}-\mathrm{n}}$ for individuals missing $\mathrm{SCL}_{\mathrm{n}-\mathrm{t}}$ were developed using linear regression:

$$
\begin{gathered}
\text { CCL }_{n-\mathrm{t}} \text { to } \mathrm{SCL}_{\mathrm{n}-\mathrm{t}}: \mathrm{SCL}_{\mathrm{n}-\mathrm{t}}= \\
6.660+0.848 \mathrm{CCL}_{\mathrm{n}-\mathrm{t} i} \mathrm{r}^{2}=0.88, \mathrm{p}<0.01 \\
\text { SCL }_{\mathrm{n}-\mathrm{n}} \text { to } \mathrm{SCL}_{\mathrm{n}-\mathrm{t}}: \mathrm{SCL}_{\mathrm{n}-\mathrm{t}}= \\
3.823+0.950 \mathrm{SCL}_{\mathrm{n}-\mathrm{n} ;} \mathrm{r}^{2}=0.94, \mathrm{p}<0.01
\end{gathered}
$$

$\mathrm{SCL}_{\mathrm{n}-\mathrm{t}}$ was recorded once per year for each female, because there is negligible within-season carapace growth, and measurements were applied to all clutches from each individual within a year. For clutches where a female was not observed nesting, genetic analyses were used to assign unknown clutches to known females (Frey et al. 2014), when possible, and $\mathrm{SCL}_{\mathrm{n}-\mathrm{t}}$ measurements were assigned if they had been taken from the known individual that year.

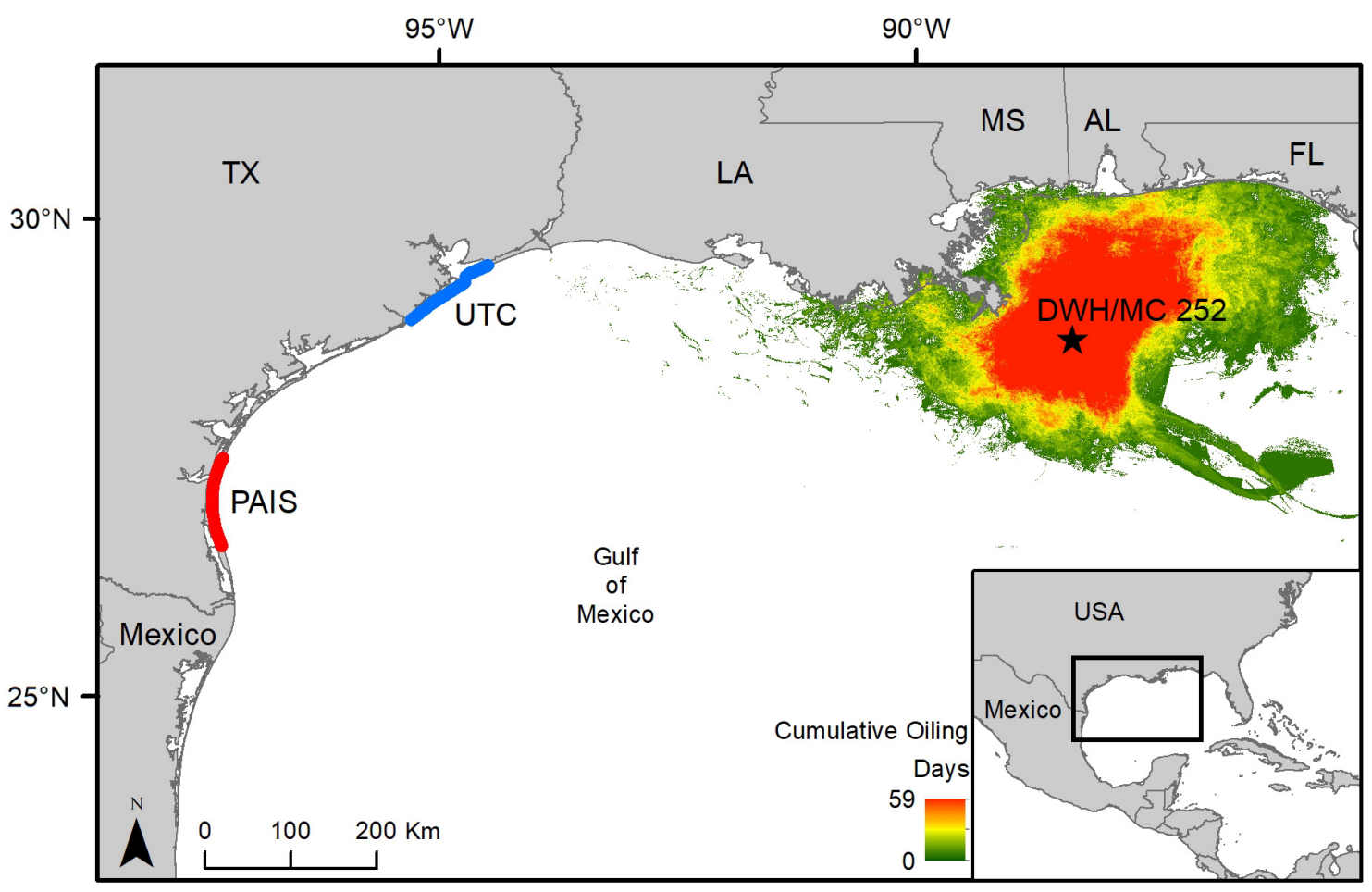

Fig. 1. Northwestern Gulf of Mexico showing study area locations of Kemp's ridley sea turtle Lepidochelys kempii nests in Texas (PAIS: Padre Island National Seashore; UTC: Upper Texas Coast), location of the Deepwater Horizon/Mississippi Canyon 252 (DWH/MC 252) wellhead ( $\star$ ), and cumulative days of surface oiling. Surface oiling data represents the Cumulative TCNNA SAR Oiling - Days of Oiling and was obtained from https://response.restoration.noaa.gov/erma (accessed 31 
At termination of incubation, hatchlings were removed from the sand surface at the first signs of activity, and nest remains, including trapped live hatchlings, were exhumed. All hatchlings were counted, and live hatchlings were released at PAIS. To expedite release of large numbers of hatchlings, limit light exposure, and to follow pre-spill techniques for accurate comparison, live hatchlings were not examined for deformities. Unhatched eggs, including those that were pipped, were salvaged and refrigerated until examination, which occurred within 6 h. Embryos were examined for the presence of grossly visible abnormalities and assigned a developmental stage at mortality (Crastz 1982). Deformities were classified as one of the following: grossly visible craniofacial, carapace, plastron, limb, pigment, and other deformities (e.g. neck and tail, edema, multiple embryos). Tissue samples were collected from 5 embryos from nests where the female was unknown for genetic matching to identified females using the kinship analysis methods described in Frey et al. (2014). The total number of embryos with each type of deformity, along with the total number of deformed embryos and the total number of late-stage ( $\geq$ stage 28; Crastz 1982) deformed embryos, were summed for each clutch for analyses and reported as percentages.

\subsection{Statistical analyses}

We considered 2010 'pre-spill' in all comparisons because $L$. kempii nesting in Texas began on 24 April (4 $\mathrm{d}$ after the spill began), and it was assumed that most turtles departed foraging areas before oil spread to these regions (Shaver et al. 2016a, Reich et al. 2017). All analyses were conducted in R v.3.6.3 (R Core Team 2020). All comparative analyses were used to determine any differences pre- and postDWH (2008-2010 vs. 2011-2013) and between incubation types/locations (PAIS-C, PAIS-I, UTC). Comparisons between specific years were not modeled because year and pre-/post-DWH variables were aliased. Preliminary data exploration was carried out following recommended protocols (Zuur et al. 2010).

A total of 34 irregular clutches (5.2\%) ranging from 2 (2010) to 9 (2009) per year were excluded from analyses to eliminate confounding factors. Clutches were excluded if they had been disturbed by predators, inundated by seawater, incubated in situ (as opposed to corral or laboratory incubation), were surgically removed from a recently deceased female, or were produced in captivity by oxytocin administra- tion. For the 6 yr period, 650 clutches were included in analyses. Two additional clutches were removed from analysis of deformity rates because they had $100 \%$ developmental failure and thus no embryos were examined.

Deformity rates (total and late-stage) for 519 clutches, where the identity of the female was known through direct observation or genetic assignment, were evaluated using generalized linear mixed models (GLMMs). Deformity rates were modeled as the proportion of 'successes' (deformed embryos/ hatchlings) and the proportion of 'failures' (normal embryos/hatchlings). Differences between specific deformity types were not analyzed, as some deformities occurred at such low frequencies that analyses could not be completed. Preliminary statistical testing indicated over-dispersion and zero-inflation of the data. Due to these factors, zero-inflated binomial GLMMs with a logit link function were used to analyze deformity rates, which incorporated a zero-model to account for excess zeroes and a binomial-model to determine the prevalence of the response. The proportions of deformities were modeled as functions of the fixed main covariates incubation type/location (categorical with 3 levels) and pre-/post-DWH (categorical with 2 levels) with nest day (continuous) as a nuisance variable. Maximum $\mathrm{SCL}_{\mathrm{n}-\mathrm{t}}$ was not included as a covariate as it was not correlated with any deformity types. Turtle identity was included as a random effect to account for non-independence of clutches from known females (i.e. multiple clutches assigned to a specific female within and between years).

Using linear regression, nesting data indicated the expected positive relationship between clutch size and $\mathrm{SCL}_{\mathrm{n}-\mathrm{t}}\left(\mathrm{r}^{2}=0.13, F_{1,464}=70.65, \mathrm{p}<0.001\right)$ (Fig. 2) (Witzell et al. 2005). A weaker negative relationship between clutch size and nest date (day of the nesting season, beginning with detection of the first nest in each study area each year) was also evident, with clutch size decreasing slightly as the nesting season progressed $\left(\mathrm{r}^{2}=0.02, F_{1,647}=13.15, \mathrm{p}<0.001\right)$ (Fig. 2). There was no significant interaction between $S L_{n-t}$ and nest date. Consequently, comparisons of clutch size between study locations and pre-/post-DWH required accounting for both nest date and $\mathrm{SCL}_{\mathrm{n}-\mathrm{t}}$. Clutch size was evaluated using a linear mixed model (LMM) and included data from 466 clutches from known females with associated $\mathrm{SCL}_{\mathrm{n}-\mathrm{t}}$ measurements. Nest data without corresponding $\mathrm{SCL}_{\mathrm{n}-\mathrm{t}}$ measurements $(n=184)$ were excluded from clutch size analyses, as $\mathrm{SCL}_{\mathrm{n}-\mathrm{t}}$ was found to have a positive relationship with clutch size. Clutch size was modeled as a function of the fixed covariates pre-/post- 

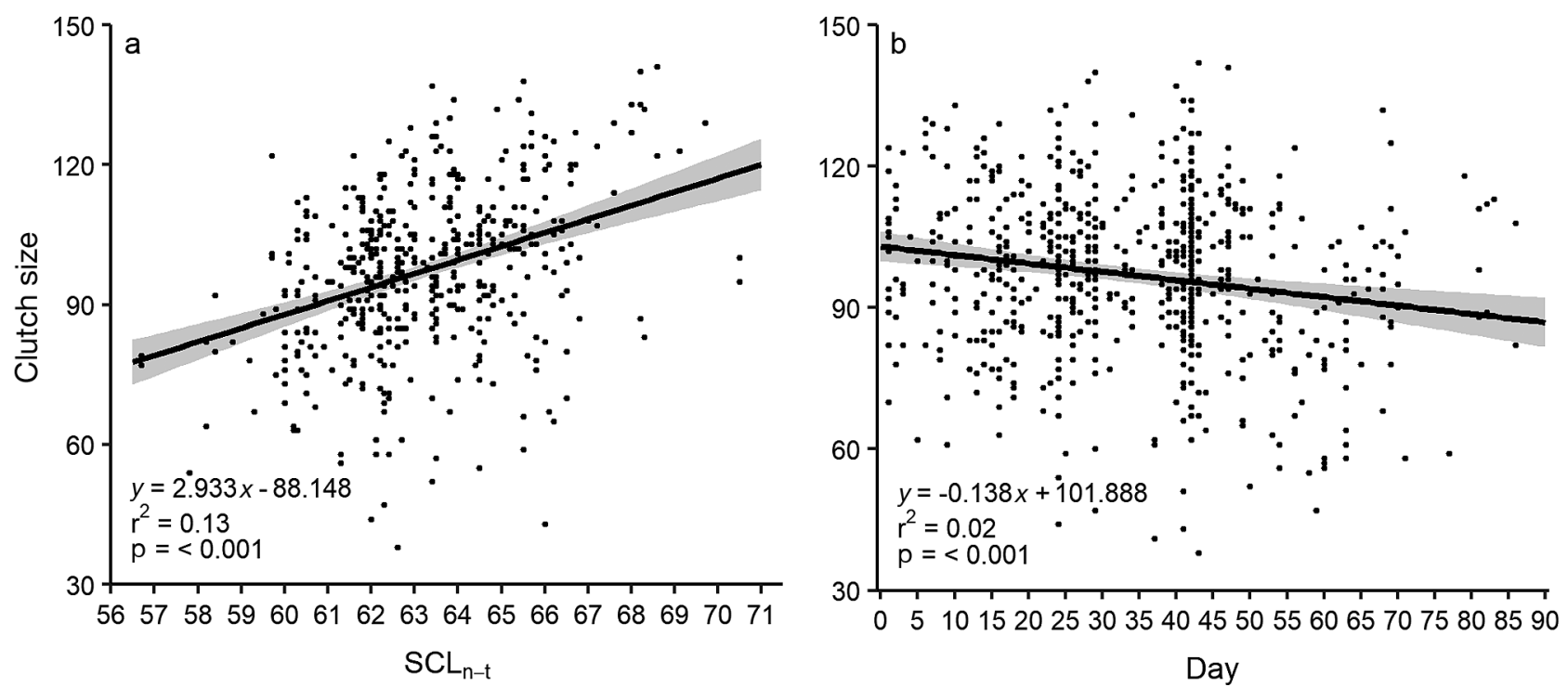

Fig. 2. Overall linear regressions describing relationship between clutch size and (a) maximum straight carapace length $\left(\mathrm{SCL}_{\mathrm{n}-\mathrm{t}}\right)$ and (b) nest day of Kemp's ridley sea turtles Lepidochelys kempii between 2008 and 2013; $95 \%$ confidence intervals shaded in gray. Clutch 2012-97, which contained only 6 eggs, was excluded from analyses

DWH, incubation type/location, $\mathrm{SCL}_{\mathrm{n}-\mathrm{t}}$ (continuous), and nest date (continuous) with turtle identity included as a random effect.

Initial analyses indicated hatching success to be highly variable within and between years, time periods, and locations. Due to these factors, it was not possible to successfully model hatching success to fit the data to determine any effects post-DWH or between incubation types/locations. Therefore, hatching success is presented as observational data only.

LMMs were conducted using the 'Ime4' package (Bates et al. 2015) and evaluated using standard methods (Zuur et al. 2010). GLMMs were conducted using the 'glmmTMB' package (Brooks et al. 2017) and were evaluated using the 'DHARMa' package (Hartig 2020). Models were fit to the data by testing the significance of each variable at each step and extracting non-significant terms (backwards stepwise) from the maximal models, using Akaike's information criterion for comparisons, until the most parsimonious (i.e. minimally adequate) model was obtained for each response variable (Crawley 2015). A significance level of $\alpha=0.05$ was used to judge the significance of all statistical tests. Interaction terms of fixed and nuisance covariates were included in maximal models (Crawley 2015), where appropriate (Zuur et al. 2010). Nakagawa's ${ }^{2}$ was used to determine the amount of variance explained by only the fixed (marginal $\mathrm{r}^{2}$ ) and both the fixed and random (conditional $\mathrm{r}^{2}$ ) effects of each final mixed model using the 'performance' package (Nakagawa \& Schielzeth 2013, Nakagawa et al. 2017, Lüdecke et al. 2020). Only the main effect means (incubation type/location and pre-/post-DWH) are presented, with the focus on before/after comparisons. All data are reported as means $\pm \mathrm{SD}$.

\section{RESULTS}

\subsection{Yearly nesting activity}

A total of 1094 Lepidochelys kempii nests were located in Texas during 2008-2013. Of these, 684 $(62.5 \%)$ were within the study area (594 [87\%] at PAIS, 90 [13\%] UTC) ranging from $53 \%$ in 2008 to $66 \%$ in 2011, consistent with 1995-2010 trends, when nesting increased in Texas (Shaver et al. 2016b). Annual nest totals ranged from 141 (2010) to 209 (2012) for all of Texas and from 88 (2010) to 132 (2011) for the study area.

Data were analyzed after exclusion of irregular clutches. Females were directly examined for size and tags at 413 of the 650 nests included in the analyses $(63.5 \%)$ during 2008-2013 (Table 1). UTC females were directly examined approximately half as often as PAIS females. An additional 108 clutches were assigned to known females using genetic analyses (Frey et al. 2014). Over the 6 yr study, using tag numbers and genetic analyses, 199 females were documented nesting only once during a nesting season, 122 were documented twice, and 26 were documented 3 times for a total of 521 clutches from 240 unique individuals (Table 1); 129 clutches were not 
Table 1. Annual numbers of Kemp's ridley sea turtle Lepidochelys kempii nests found in Texas, within Padre Island National Seashore (PAIS), and on the Upper Texas Coast (UTC) study areas (SA) from 2008-2013, excluding nests not suitable for analysis. UTC-I: nests located on the UTC, incubated in the laboratory facility; PAIS-C: nests at PAIS, incubated in corrals; PAIS-I: nests at PAIS, incubated in the laboratory facility; total SA: nests combined for the 2 study areas; total TX: total number of nests in Texas, including those excluded from analysis; females in study areas: number of females directly observed or genetically matched to nests within each year or time period; nests per female: SA nests with a female identified divided by the number of females; nests with female: nests where the female was identified either by observation or genetic matching;

ND: not determined; NA: not applicable

\begin{tabular}{|c|c|c|c|c|c|c|}
\hline $\begin{array}{l}\text { Year (no. excluded), } \\
\text { location/parameter }\end{array}$ & All nests & $\begin{array}{l}\text { Nests with } \\
\text { female }\end{array}$ & \multicolumn{2}{|c|}{$\begin{array}{l}\text { Year (no. excluded), } \\
\text { location/parameter }\end{array}$} & All nests & $\begin{array}{l}\text { Nests with } \\
\text { female }\end{array}$ \\
\hline $2008(5)$ & & & \multicolumn{2}{|c|}{$2011(5)$} & & \\
\hline UTC-I & 13 & 8 & \multicolumn{2}{|c|}{ UTC-I } & 18 & 12 \\
\hline PAIS-C & 11 & 7 & \multicolumn{2}{|c|}{ PAIS-C } & 37 & 30 \\
\hline PAIS-I & 80 & 68 & \multicolumn{2}{|c|}{ PAIS-I } & 77 & 69 \\
\hline Total SA & 104 & 83 & \multicolumn{2}{|c|}{ Total SA } & 132 & 111 \\
\hline Total TX & $195^{\mathrm{a}}$ & ND & \multicolumn{2}{|c|}{ Total TX } & $199^{\mathrm{a}}$ & ND \\
\hline Females in study areas & NA & 52 & \multicolumn{2}{|c|}{ Females in study areas } & NA & 69 \\
\hline Nests per female & NA & $1.6 \pm 0.7$ & \multicolumn{2}{|c|}{ Nests per female } & NA & $1.6 \pm 0.6$ \\
\hline $2009(9)$ & & & \multicolumn{2}{|c|}{$2012(7)$} & & \\
\hline UTC-I & 7 & 2 & \multicolumn{2}{|c|}{ UTC-I } & 12 & 8 \\
\hline PAIS-C & 23 & 18 & \multicolumn{2}{|c|}{ PAIS-C } & 34 & 29 \\
\hline PAIS-I & 89 & 78 & \multicolumn{2}{|c|}{ PAIS-I } & 66 & 54 \\
\hline Total SA & 119 & 98 & \multicolumn{2}{|c|}{ Total SA } & 112 & 91 \\
\hline Total TX & $197^{\mathrm{a}}$ & ND & \multicolumn{2}{|c|}{ Total TX } & $209^{\mathrm{a}}$ & ND \\
\hline Females in study areas & NA & 68 & \multicolumn{2}{|c|}{ Females in study areas } & NA & 58 \\
\hline Nests per female & NA & $1.2 \pm 0.6$ & \multicolumn{2}{|c|}{ Nests per female } & NA & $1.6 \pm 0.7$ \\
\hline $2010(2)$ & & & \multicolumn{2}{|c|}{$2013(6)$} & & \\
\hline UTC-I & 15 & 8 & \multicolumn{2}{|c|}{ UTC-I } & 13 & 5 \\
\hline PAIS-C & 21 & 17 & \multicolumn{2}{|c|}{ PAIS-C } & 27 & 24 \\
\hline PAIS-I & 52 & 41 & \multicolumn{2}{|c|}{ PAIS-I } & 55 & 43 \\
\hline Total SA & 88 & 66 & \multicolumn{2}{|c|}{ Total SA } & 95 & 72 \\
\hline Total TX & $141^{\mathrm{a}}$ & ND & \multicolumn{2}{|c|}{ Total TX } & $153^{\mathrm{a}}$ & ND \\
\hline Females in study areas & NA & 47 & \multicolumn{2}{|c|}{ Females in study areas } & NA & 53 \\
\hline \multirow[t]{10}{*}{ Nests per female } & NA & $1.4 \pm 0.5$ & \multicolumn{2}{|c|}{ Nests per female } & NA & $1.4 \pm 0.6$ \\
\hline & & $\begin{array}{l}\text { Year (no. excluded), } \\
\text { location/parameter }\end{array}$ & All nests & $\begin{array}{l}\text { Nests with } \\
\text { female }\end{array}$ & & \\
\hline & & Six-year totals (34) & & & & \\
\hline & & UTC-I & 78 & 43 & & \\
\hline & & PAIS-C & 153 & 125 & & \\
\hline & & PAIS-I & 419 & 353 & & \\
\hline & & Total SA & 650 & 521 & & \\
\hline & & Total TX & $1094^{\mathrm{a}}$ & ND & & \\
\hline & & Females in study areas & NA & 347 & & \\
\hline & & Nests per female & NA & $1.5 \pm 0.6$ & & \\
\hline
\end{tabular}

assigned to a female. These unassigned nests were laid by unobserved nesting females who may have been first time nesters, turtles that nested previously in the study area but evaded detection, or turtles that have nested in the study area for the first time but nested elsewhere previously, thus identity could not be assigned. These clutches were not included in the mixed models. Unique females documented nesting in each year ranged from 47 (2010) to 69 (2011) (Table 1). No individuals were observed to have switched between PAIS and UTC to nest within a nesting season. Turtles were documented to nest an average of $1.5 \pm 0.6$ times $\mathrm{yr}^{-1}$, with the same rate before and after the spill $\left(1.5 \pm 0.6\right.$ nests $\mathrm{yr}^{-1}$ from 2008-2010 and 2011-2013) (Table 1).

Maximum $\mathrm{SCL}_{\mathrm{n}-\mathrm{t}}$ measurements were available for females of 459 clutches and estimated for an additional 7 clutches $\left(\mathrm{n}=4 \mathrm{CCL}_{\mathrm{n}-\mathrm{t}} ; \mathrm{n}=3 \mathrm{SCL}_{\mathrm{n}-\mathrm{t}}\right)$, resulting in a total of 466 clutches from 347 measured females. Average size was $63.1 \pm 2.1 \mathrm{~cm} \mathrm{SCL}_{\mathrm{n}-\mathrm{t}}$ with 
no apparent differences between study areas (PAIS: $63.2 \pm 2.1 \mathrm{~cm}$; UTC: $62.5 \pm 1.6 \mathrm{~cm}$ ) or pre-/post-DWH (2008-2010: $63.0 \pm 2.1 \mathrm{~cm} ;$ 2011-2013: $63.2 \pm 2.1 \mathrm{~cm})$. The total number of measured individuals is greater than 240, as known individuals returned to nest in more than one season, with new measurements obtained each year they were seen.

\subsection{Embryo deformities}

Two clutches from UTC, laid by the same female in 2010, had $100 \%$ developmental failure and were not included in deformity analyses. After the exclusion of these 2 clutches, 648 clutches were analyzed for general summary statistics and a total of 459 deformed dead embryos were observed in 241 clutches (37.2\%) at an overall rate of $0.7 \pm 8.5 \%$ clutch $^{-1}$ (Table 2 ). The majority of deformities were late-stage (developmental stage 28 or later; overall $0.6 \pm 8.0 \%$ nest $^{-1}$ ). Nine of the clutches with the greatest percentages of deformed embryos ( $>5 \%, \mathrm{n}=11)$ were from 2011 or 2012, while 2 were from 2009. All clutches with elevated deformity rates, except one, were laid at PAIS.

From the 519 clutches laid by known females, excluding the 2 failed clutches, there were no significant interactions between variables, and incubation/ location type and nest date were also non-significant and were removed from the models to create the minimally adequate GLMMs which included pre-/ post DWH as the main effect, and turtle identity as a random effect. Final models indicated a 1.5 times higher rate of total number of deformities and of total late-stage deformities in $L$. kempii clutches post-DWH (total deformities: pre-DWH $=0.8 \pm 0.1 \%$, post-DWH
$=1.15 \pm 0.2 \%, \mathrm{p}<0.01$; late-stage deformities: pre$\mathrm{DWH}=0.6 \pm 0.1 \%$, post-DWH $=0.9 \pm 0.2 \%, \mathrm{p}<0.01$ ) (Fig. 3, Table 3). Inclusion of the random effect increased the explanatory power of each GLMM (total deformities: marginal $\mathrm{r}^{2}=0.01$, conditional $\mathrm{r}^{2}=$ 0.14 ; late-stage deformities: marginal $r^{2}=0.01$, conditional $\left.r^{2}=0.18\right)$, but model explanation of the variability was low overall.

Craniofacial and carapace deformities were the most frequently recorded deformity types; a total of 215 embryos with craniofacial deformities and 174 with carapace deformities were observed, which represented a prevalence of $0.3 \pm 5.8$ and $0.3 \pm 5.2 \%$, respectively, across all years and locations (Fig. 4). Other types of deformities were detected less frequently (pigment, $\mathrm{n}=86,0.1 \pm 3.7 \%$; limb, $\mathrm{n}=62,0.1$ $\pm 3.1 \%$; other, $\mathrm{n}=62,0.1 \pm 3.1 \%$; and plastron, $\mathrm{n}=$ $51,0.1 \pm 2.8 \%$; Fig. 4). All types of deformities occurred more frequently in clutches in 2011-2013 than in 2008-2010 (Table 2).

\subsection{Clutch size and hatching success}

The 650 clutches included in general summary statistical analyses contained 63138 eggs during 20082013, of which 55140 hatched (87.3\%) and from which 54981 hatchlings (87.1\%) emerged and were released (Table 4 ). Over the 6 yr study, $99.7 \pm 5.4 \%$ of the turtles that hatched survived and were released. For the 466 clutches from known females with associated $\mathrm{SCL}_{\mathrm{n}-\mathrm{t}}$ measurements, clutch size did not significantly differ pre- and post-DWH $(\mathrm{p}=0.28)$ but did differ between locations, with PAIS-I and PAIS-C having lower average clutch sizes (PAIS-I: $p<0.01$;

Table 2. Annual, total, and pre- (2008-2010)/post- (2011-2013) Deepwater Horizon numbers of clutches included in the 20082013 Kemp's ridley Lepidochelys kempii analysis of dead embryos with deformities after exclusion of all disturbed, abnormal, and failed clutches $(n=36)$. Late-stage embryos: deformities in embryos stage 28 and higher; 'other' deformity types include neck and tail, edema, multiple embryos and other unclassified deformities. Values in parentheses are percentages of total clutches for the category

\begin{tabular}{|c|c|c|c|c|c|c|c|c|c|}
\hline \multirow[t]{2}{*}{ Year } & \multirow{2}{*}{ Clutches } & \multicolumn{8}{|c|}{ Deformities } \\
\hline & & $\begin{array}{c}\text { All types } \\
(\%)\end{array}$ & $\begin{array}{c}\text { Late-stage } \\
(\%)\end{array}$ & $\begin{array}{c}\text { Craniofacial } \\
(\%)\end{array}$ & $\begin{array}{c}\text { Carapace } \\
(\%)\end{array}$ & $\begin{array}{c}\text { Plastron } \\
(\%)\end{array}$ & $\begin{array}{c}\operatorname{Limb} \\
(\%)\end{array}$ & $\begin{array}{c}\text { Pigment } \\
(\%)\end{array}$ & $\begin{array}{l}\text { Other } \\
(\%)\end{array}$ \\
\hline 2008 & 104 & $24(23.1)$ & $23(22.1)$ & $9(8.7)$ & $5(4.8)$ & $1(1.0)$ & $6(5.8)$ & $4(3.8)$ & $8(7.7)$ \\
\hline 2009 & 119 & $46(38.7)$ & $44(37.0)$ & $24(20.2)$ & $18(15.1)$ & $2(1.7)$ & $6(5.0)$ & $9(7.6)$ & $15(12.6)$ \\
\hline 2010 & 86 & $28(32.6)$ & $25(29.1)$ & $17(19.8)$ & $4(4.7)$ & $1(1.2)$ & $3(3.5)$ & $7(8.1)$ & $1(1.2)$ \\
\hline 2011 & 132 & $48(36.4)$ & $47(35.6)$ & 34 (25.8) & $25(18.9)$ & $12(9.1)$ & 11 (8.3) & $15(11.4)$ & $7(5.3)$ \\
\hline 2012 & 112 & $56(50.0)$ & $54(48.2)$ & 38 (33.9) & $39(34.8)$ & $14(12.5)$ & $13(11.6)$ & $15(13.4)$ & $11(9.8)$ \\
\hline 2013 & 95 & 39 (41.1) & 37 (38.9) & $24(25.3)$ & $20(21.1)$ & $14(14.7)$ & $16(16.8)$ & 15 (15.8) & $12(12.6)$ \\
\hline Total & 648 & $241(37.2)$ & $230(35.5)$ & $146(22.5)$ & $111(17.1)$ & $44(6.8)$ & $55(8.5)$ & $65(10.0)$ & $54(8.3)$ \\
\hline 2008-2010 & 309 & $98(31.7)$ & $92(29.8)$ & $50(16.2)$ & $27(8.7)$ & $4(1.3)$ & $15(4.9)$ & $20(6.5)$ & $24(7.8)$ \\
\hline 2011-2013 & 339 & $143(42.2)$ & $138(40.7)$ & $96(28.3)$ & $84(24.8)$ & $40(11.8)$ & $40(11.8)$ & 45 (13.3) & $30(8.8)$ \\
\hline
\end{tabular}



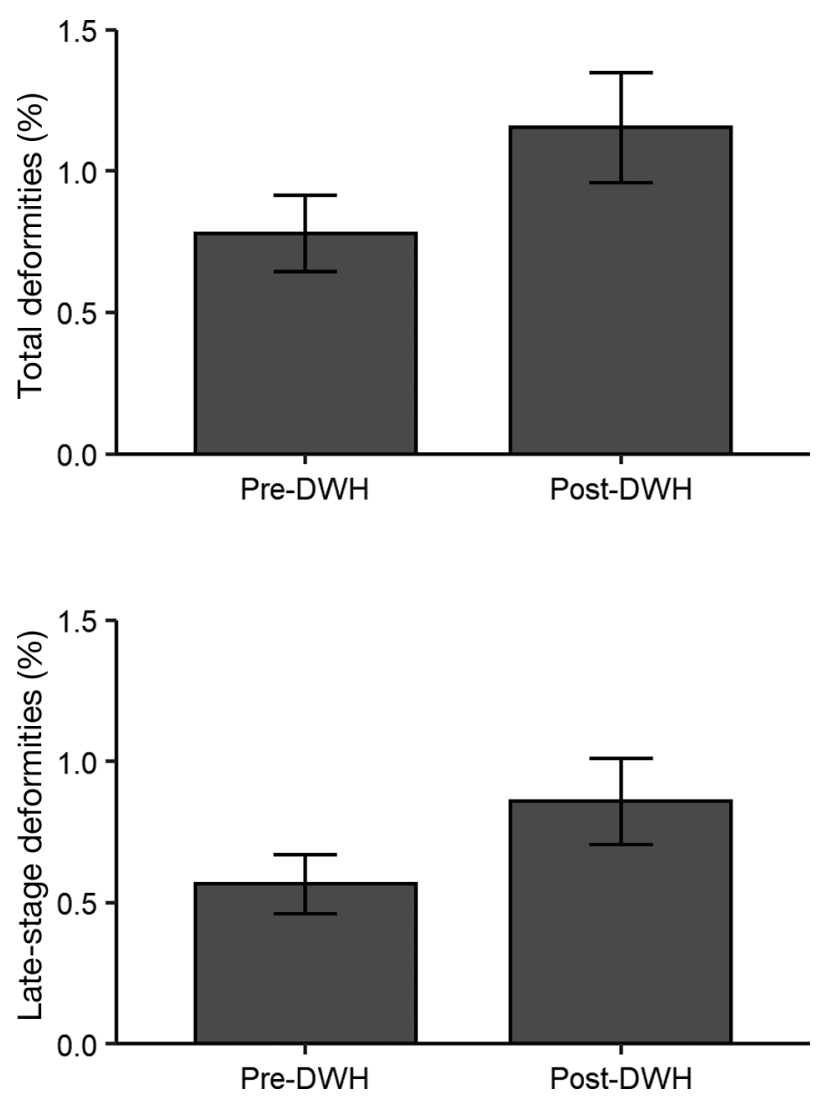

Fig. 3. Zero-inflated generalized linear mixed model results of the proportion of total and late-stage deformities of embryos found in Lepidochelys kempii clutches laid along the Texas, USA, coast pre- (2008-2010) and post- (2011-2013) Deepwater Horizon (DWH). Error bars: $\pm 1 \mathrm{SE}$
PAIS-C: $\mathrm{p}<0.05$ ) (Fig. 5, Table 3). Inclusion of the random effect increased the overall explanatory power of the LMM (marginal $\mathrm{r}^{2}=0.20$, conditional $\mathrm{r}^{2}$ $=0.41$ ). Overall hatching success was $87.3 \pm 33.3 \%$ for the 6 yr period, $87.8 \pm 32.7 \%$ pre-DWH, and 86.9 $\pm 33.8 \%$ post-DWH. Hatching success was highly variable among nests from different locations within the study area, with higher rates of success for PAISI $(88.4 \pm 32.0 \%)$ and PAIS-C $(91.1 \pm 28.5 \%)$ than UTC $(74.5 \pm 43.6 \%)$.

\section{DISCUSSION}

International conservation efforts implemented since the mid-1970s resulted in an exponential increase of Lepidochelys kempii nests documented each year from 1999-2009 (Caillouet 2011, Gallaway et al. 2016a,b, Shaver et al. 2016b, Wibbels \& Bevan 2016). However, nest numbers in Mexico and Texas, which are highly correlated and represent portions of the same nesting population (Shaver et al. 2016b), decreased $37 \%$ in 2010 relative to 2009, as did the number of hatchlings released (Crowder \& Heppell 2011), representing a major departure from trends in previous years. Nest numbers remained lower than predicted after the DWH spill (Bevan et al. 2016, Gallaway et al. 2016b, Shaver et al. 2016b) and did not begin to increase again until 2016. Nesting has not resumed the exponential increase observed prior to DWH, causing further concern for the sta-

Table 3. Results of generalized and general linear mixed effects models (GLMM/LMM) of deformity rates and clutch size in Lepidochelys kempii clutches before (2008-2010) and after (2011-2013) the Deepwater Horizon (DWH) oil spill. Deformity rates were modeled using a zero-inflated binomial GLMM with logit link; clutch size was modeled using an LMM. PAIS-I: Padre Island National Seashore incubation facility; PAIS-C: Padre Island National Seashore corral; $\mathrm{SCL}_{\mathrm{n}-\mathrm{t}}$ : straight carapace length, nuchal notch to posterior tip (cm)

\begin{tabular}{|c|c|c|c|c|c|}
\hline \multirow[t]{2}{*}{ Model } & \multirow[t]{2}{*}{ Variable } & \multicolumn{2}{|c|}{ Unstandardized coefficients } & \multirow[t]{2}{*}{$z$} & \multirow[t]{2}{*}{$\mathrm{p}$} \\
\hline & & Estimate & SE & & \\
\hline \multirow[t]{2}{*}{ Total deformities (conditional) } & Intercept & -4.846 & 0.174 & -27.909 & $<0.001$ \\
\hline & Pre-/post-DWH [post] & 0.396 & 0.145 & 2.732 & $<0.01$ \\
\hline Total deformities (zero) & Intercept & -0.558 & 0.244 & -2.288 & $<0.05$ \\
\hline \multirow[t]{2}{*}{ Late-stage deformities (conditional) } & Intercept & -5.170 & 0.186 & -27.874 & $<0.001$ \\
\hline & Pre-/post-DWH [post] & 0.420 & 0.148 & 2.836 & $<0.01$ \\
\hline Late-stage deformities (zero) & Intercept & -0.935 & 0.332 & $\begin{array}{c}-2.812 \\
t\end{array}$ & $<0.01$ \\
\hline \multirow[t]{6}{*}{ Clutch size } & Intercept & -79.747 & 25.074 & -3.180 & $<0.01$ \\
\hline & Pre-/post-DWH [post] & 1.584 & 1.472 & 1.076 & 0.283 \\
\hline & Location [PAIS-C] & -7.482 & 3.673 & -2.037 & $<0.05$ \\
\hline & Location [PAIS-I] & -9.930 & 3.444 & -2.884 & $<0.01$ \\
\hline & $S C L_{n-t}$ & 3.022 & 0.398 & 7.593 & $<0.001$ \\
\hline & Nest date & -0.204 & 0.041 & -5.040 & $<0.001$ \\
\hline
\end{tabular}



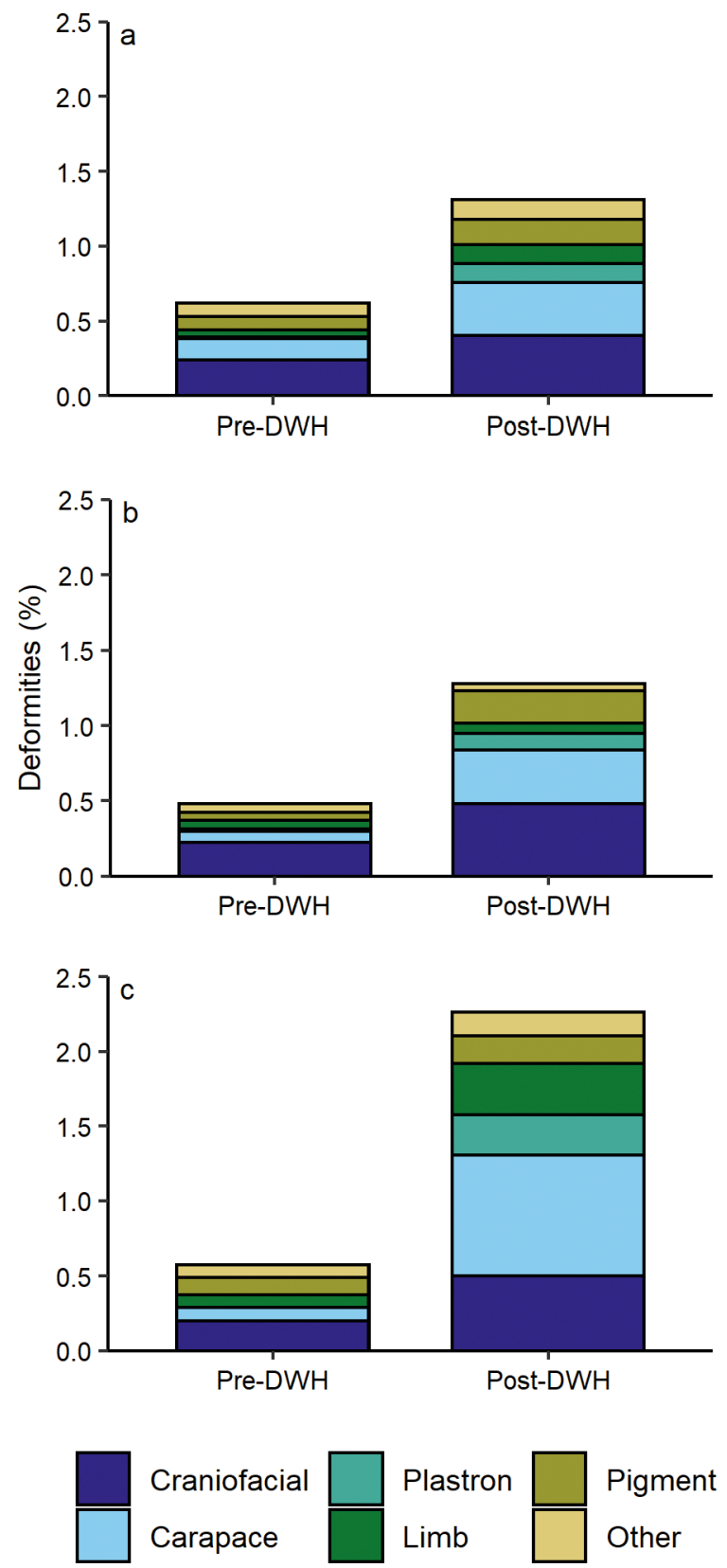

Fig. 4. Mean prevalence (un-weighted proportional means) of embryo deformity types (as percentages of clutch size) in Kemp's ridley sea turtle Lepidochelys kempii clutches, pre(2008-2010) and post- (2011-2013) Deepwater Horizon (DWH) at (a) Padre Island National Seashore incubation facility (PAIS-I); (b) Padre Island National Seashore corral (PAIS-C), and (c) upper Texas coast (UTC)

tus of this species (Gallaway et al. 2016b, Caillouet et al. 2018).

Most L. kempii nesting occurs on the Gulf coast of Mexico in Tamaulipas and Veracruz and to a lesser extent in Texas (Shaver et al. 2016b). Nearshore waters of the northern Gulf, the same geographic area affected by the DWH oil spill, provide particularly important foraging and migratory habitat for L. kempii that migrate from nesting beaches in Texas and Mexico (Shaver \& Rubio 2008, Shaver et al. 2013, 2016a, Putman et al. 2015, Wallace et al. 2017, Gredzens \& Shaver 2020). Impacts from the DWH oil spill, if present, may have directly affected nesting females (oiling or disturbance) or indirectly affected them via ingestion of oil or related compounds from the water column or dietary sources (Zychowski \& Godard-Codding 2017). Anthropogenic activities post-DWH, such as increased boat traffic during clean-up, may also have had detrimental effects on marine turtle populations (Lauritsen et al. 2017). It is unknown if oil contamination of the foraging grounds affected reproductive success and, ultimately, the observed slowed population recovery.

Deformity rates were higher in examined L. kempii embryos post-DWH. Statistical models explained a comparatively small proportion of the total variation in the data, thus indicating that factors not incorporated into the models are likely important. Possible confounding variables could be error introduced by embryo deformity examiners and/or a possible increased scrutiny of embryo examination after the oil spill due to awareness of the study. Future studies should work to mitigate these types of confounding factors. For this study, live hatchlings were not examined for deformities in order to protect them from exposure to white light and allow for quick release. Analysis of the data based only on females observed and examined while nesting or genetically matched to clutches indicates that differences between or among nests made by the same turtle account for substantially more of the total variation for some of the variables analyzed. Deformed embryo prevalence was low overall and highly variable $(0.7 \pm 8.5 \%)$, indicating probable low population-level impacts. In comparison, turtle embryo deformities from John Heinz National Wildlife Refuge, which is highly contaminated by multiple sources, ranged from 13-71\% annually in 2 freshwater species, Chelydra serpentina and Chrysemys picta (Bell et al. 2006). Frequency of malformations for marine turtle eggs has also been reported in other species of marine turtles, for both in situ and relocated nests, ranging from $0.2-26.0 \%$, with high variability between species and locations (Bárcenas-Ibarra et al. 2015). Embryo malformation rates for the most closely related species of marine turtle, the olive ridley Lepidochelys olivacea, are relatively high (1-2\%) when compared to other species (Bárcenas-Ibarra et al. 2015).

Annual clutch size and frequency were monitored for changes after the spill, as fecundity is critical to 
Table 4. Annual, total, and pre- (2008-2010)/post- (2011-2013) Deepwater Horizon clutch size and nest success for Kemp's ridley Lepidochelys kempii within the study area after exclusion of all disturbed and abnormal clutches $(\mathrm{n}=34)$. Values in parentheses are percentages of total eggs/hatchlings for the category

\begin{tabular}{|lcccrr|}
\hline Year & Total clutches & Total eggs (\%) & Hatched eggs (\%) & Unhatched eggs (\%) & Hatchlings released (\%) \\
\hline 2008 & 104 & $10117(16.0)$ & $9207(91.0)$ & $910(9.0)$ & $9196(90.9)$ \\
2009 & 119 & $11210(17.8)$ & $9668(86.2)$ & $1542(13.8)$ & $9644(86.0)$ \\
2010 & 88 & $8581(13.6)$ & $7399(86.2)$ & $1182(13.8)$ & $7385(86.1)$ \\
2011 & 132 & $13173(20.9)$ & $11421(86.7)$ & $1752(13.3)$ & $11378(86.4)$ \\
2012 & 112 & $10898(17.3)$ & $9468(86.9)$ & $1430(13.1)$ & $9438(86.6)$ \\
2013 & 95 & $9159(14.5)$ & $7977(87.1)$ & $1182(12.9)$ & $7940(86.7)$ \\
Total & 650 & 63138 & $55140(87.3)$ & $7998(12.7)$ & $54981(87.1)$ \\
$2008-2010$ & 311 & $29908(47.4)$ & $26274(87.8)$ & $3634(12.2)$ & $2625(87.7)$ \\
$2011-2013$ & 339 & $33230(52.6)$ & $28866(86.9)$ & $4364(13.1)$ & $28756(86.5)$ \\
\hline
\end{tabular}

long-term population dynamics. For grouped years, 2008-2010 (pre-DWH) vs. 2011-2013 (post-DWH), clutch size was not significantly different, but did differ between study locations after accounting for turtle size and nest date, with larger clutches found on the UTC. Differences in clutch size between locations are likely the result of more nesting at PAIS paired with increased patrol effort there late in the nesting season (August-September) (Shaver et al. 2016b). Analysis indicated that nesting day may affect clutch size, with smaller clutches later in the season (Fig. 2b). Other factors may also contribute, as the explanatory power of the model was low. In addition, there may be other unexplained factors as to why UTC clutch sizes are larger, such as mean individual age or health or the closer proximity of the UTC to important foraging areas (Shaver et al. 2013, 2016a).
Over 36 yr (1978-2014), annual mean clutch size did not vary greatly for $L$. kempii nesting in Texas (Shaver et al. 2016b). Considered together, the number of nests detected per known female was the same in 2011-2013 (1.5 \pm 0.6) and 2008-2010 (1.5 \pm 0.6). However, identified turtles undoubtedly made some of the nests laid by unidentified females, indicating that the number of nests per female is lower than the estimated total at 1.8 nests $\mathrm{yr}^{-1}$ (Frey et al. 2014, Shaver et al. 2016b).

Hatching success for $L$. kempii nests in the study areas was monitored for changes after DWH. However, no significant differences in hatching success between 2008-2010 and 2011-2013 were found due to high variability in the data. Hatch success is very complex and is impacted by many factors (e.g. nest temperature, moisture, sand quality, genetics, health
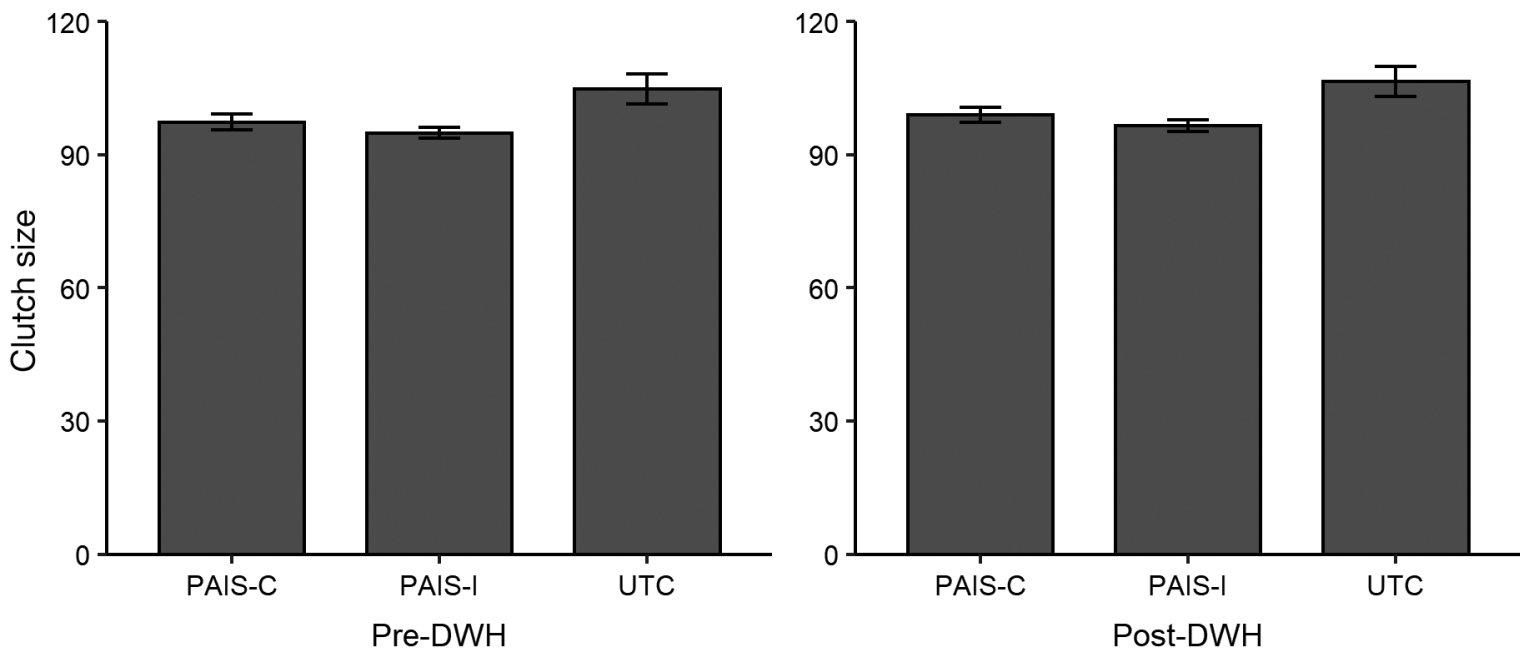

Incubation type/Location

Fig. 5. Linear mixed model results of Kemp's ridley sea turtle Lepidochelys kempii clutch size pre- (2008-2010) and post(2011-2013) Deepwater Horizon (DWH) divided by incubation type and location. PAIS-C: Padre Island National Seashore corral; PAIS-I: Padre Island National Seashore incubation facility; UTC: Upper Texas coast incubated at PAIS-I. Error bars: \pm 1 SE 
status of the nesting female), some of which are difficult to quantify for the purpose of analysis. For example, individual L. kempii experience complete developmental failure of clutches on rare occasions for unknown reasons during a nesting season (Backof et al. 2019). For these reasons, this parameter may be of limited benefit in future studies examining shortterm impacts of oil spills, unless the impacts are profound. Long-term impacts of persistent environmental exposure (Peterson et al. 2003), ontogenetic effects (Bell et al. 2006), or latency factors may delay detectability for many years.

The timing of the spill likely mitigated impacts to $L$. kempii during 2010, as females nesting during that season migrated away from the oiled habitat to nesting grounds prior to the spill (Shaver et al. 2016a). Data from satellite-tracked adult nesting females and stable isotope samples indicated that $51.5 \%$ of the L. kempii in the northern GOM may have been exposed to DWH oil in 2010-2012 (Reich et al. 2017), consistent with other reports of marine turtle interactions with oil in the northern GOM (McDonald et al. 2017, Wallace et al. 2017). These assumptions are further supported by the fact that chemical analyses of eggs and embryos salvaged from 2010-2012 nests contained no detectable, or extremely low, concentrations of oil metabolites (Hooper \& Schmitt 2015). These observations do not preclude the possible involvement of the spill in the lower than expected nest numbers in Texas and Mexico during 2011-2015 (Crowder \& Heppell 2011, Shaver et al. 2016b) (i.e. in addition to direct mortalities of adult turtles, oilaffected turtles that survived the spill may not have migrated and/or nested).

Observations of nesting turtles and nest success represent only the beginning and the end of the marine turtle reproductive cycle. Tracking data from 2010-2013 indicate that many nesting female $L$. kempii traveled in the oiled area after nesting in Texas (Shaver et al. 2016a, Gredzens \& Shaver 2020), and immature turtles exposed to oil from the DWH spill and the progeny of exposed adults will not mature for many years. Impacts observed in this study remain low but could be drastically different if a similar environmental disaster occurred closer to the main nesting areas (Lauritsen et al. 2017), where significant numbers of oil and gas platforms overlap with critical habitat (Shaver et al. 2017). There is significant potential for future catastrophic oil releases within critical foraging habitat and L. kempii nesting beaches (Shaver et al. 2017). Continued evaluation of data from nesting beaches (i.e. nest numbers, nest success, remigration intervals, growth rates, and re- cruitment) is necessary to provide evidence of whether oil contamination at the foraging grounds affects reproductive success and, ultimately, population recovery. Data and methods reported here represent useful benchmarks against which to judge impacts to marine turtles by future oil spills and can serve as a basis for future investigations to prepare for, and respond to, damages caused.

Acknowledgements. This study was supported by the US Department of the Interior, Natural Resource Damage Assessment and Restoration Program; the National Park Service; and the US Geological Survey (USGS). Field activities at PAIS were coordinated by the PAIS Sea Turtle Science and Recovery Program and at UTC by the Texas A\&M University - Galveston Trophic Ecology and Sea Turtle Research Laboratory. Sampling at PAIS was authorized under US Fish and Wildlife Service (USFWS) Permit TE840727-3 and Texas Parks and Wildlife Department (TPWD) Scientific Permit SPR-0190-122 and performed in accordance with Institutional Animal Care Protocol NPS IACUC 2011-15. UTC sampling was conducted under and in accordance with IACUC AUP 2010-213 and authorized under USFWS permit TE7761 and TPWD permit SPR-0212-028. M. Hooper (USGS), T. Shearer (USFWS), and S. Finger (USGS) facilitated many aspects of the investigation. R. Tillitt (USGS) guided initial laboratory technique development and assisted in the field and with data management. Additional field and laboratory assistance were provided by C. Iseton and K. Reich. We greatly appreciate comments on earlier versions of the manuscript provided by K. M. Hart (USGS), T. Backof (NPS), M. Tiwari, NOAA, the editors, and 3 anonymous reviewers. Some of the work by C.J.S. was done while serving as a volunteer with the USGS. Any use of trade, product, or firm names is for descriptive purposes only and does not constitute endorsement by the US Government.

\section{LITERATURE CITED}

Antonio FJ, Mendes RS, Thomaz SM (2011) Identifying and modeling patterns of tetrapod vertebrate mortality rates in the Gulf of Mexico oil spill. Aquat Toxicol 105:177-179

Backof TF, Shaver DJ, Walker JS (2019) Describing transient infertility in Kemp's ridley sea turtle (Lepidochelys kempii) in Texas, USA. Herpetol Rev 50:272-274

Bárcenas-Ibarra A, De la Cueva H, Rojas-Lleonart I, AbreuGrobois FA, Lozano-Guzmán R, Cuevas E, Garcia-Gasca A (2015) First approximation to congenital malformation rates in embryos and hatchlings of sea turtles. Birth Defects Res A Clin Mol Teratol 103:203-224

* Bates D, Mächler M, Bolker BM, Walker S (2015) Fitting linear mixed-effects models using lme4. J Stat Softw 67: $1-48$

Bell B, Spotila JR, Congdon J (2006) High incidence of deformity in aquatic turtles in the John Heinz National Wildlife Refuge. Environ Pollut 142:457-465

Kevan EM, Wibbels T, Najera BMZ, Sarti L and others (2016) Estimating the historic size and current status of the Kemp's ridley sea turtle (Lepidochelys kempii) population. Ecosphere $7: \mathrm{e} 01244$

*Beyer J, Trannum HC, Bakke T, Hodson PV, Collier TK (2016) Environmental effects of the Deepwater Horizon 
oil spill: a review. Mar Pollut Bull 110:28-51

Bonisoli-Alquati A, Stouffer PC, Turner RE, Woltmann S, Taylor SS (2016) Incorporation of Deepwater Horizon oil in a terrestrial bird. Environ Res Lett 11:114023

Brooks ME, Kristensen K, van Benthem KJ, Magnusson A and others (2017) GlmmTMB balances speed and flexibility among packages for zero-inflated generalized linear mixed modeling. R J 9:378-400

Caillouet CW Jr (2011) Did the BP-Deepwater HorizonMacondo oil spill change the age structure of the Kemp's ridley sea turtle? Mar Turtle Newsl 130:1-2

Caillouet CW Jr, Raborn SW, Shaver DJ, Putman NF, Gallaway BJ, Mansfield KL (2018) Did declining carrying capacity for the Kemp's ridley sea turtle population within the Gulf of Mexico contribute to the nesting setback in 2010-2017? Chelonian Conserv Biol 17:123-133

Cherrier J, Sarkodee-Adoo J, Guilderson TP, Chanton JP (2014) Fossil carbon in particulate organic matter in the Gulf of Mexico following the Deepwater Horizon event. Environ Sci Technol Lett 1:108-112

Crastz F (1982) Embryological stages of the marine turtle Lepidochelys olivacea (Eschscholtz). Rev Biol Trop 30: 113-120

Crawley MJ (2015) Statistics: an introduction using R, $2^{\text {nd }}$ edn. John Wiley \& Sons, Chichester

Crowder LB, Heppell SS (2011) The decline and rise of a sea turtle: how Kemp's ridleys are recovering in the Gulf of Mexico. Solut J 2:67-73

DWH NRDA Trustees (2016) Deepwater Horizon oil spill final programmatic damage assessment and restoration plan and final programmatic environmental impact statement. NOAA, Silver Spring, MD

Field CL, Staggs L, Godard-Codding C (2017) Sea turtles and oil. In: Manire CA, Norton TM, Stacy BA, Innis CJ, Harms CA (eds) Sea turtle health and rehabilitation. J Ross Publishing, Plantation, FL, p 915-932

Frey A, Dutton PH, Shaver DJ, Walker JS, Rubio C (2014) Kemp's ridley Lepidochelys kempii nesting abundance in Texas, USA: a novel approach using genetics to improve population census. Endang Species Res 23:63-71

Fritts TH, McGehee MA (1982) Effects of petroleum on the development and survival of marine turtle embryos. Biological Services Program, Fish and Wildlife Service, Belle Chasse, LA

Gallaway BJ, Gazey WJ, Caillouet CW Jr, Plotkin PT and others (2016a) Development of a Kemp's ridley sea turtle stock assessment model. Gulf Mex Sci 33:138-157

Gallaway BJ, Gazey WJ, Wibbels T, Bevan EM, Shaver DJ, George J (2016b) Evaluation of the status of the Kemp's ridley sea turtle after the 2010 Deepwater Horizon oil spill. Gulf Mex Sci 2016:192-205

Gredzens C, Shaver DJ (2020) Satellite tracking can inform population-level dispersal to foraging grounds of postnesting Kemp's ridley sea turtles. Front Mar Sci 7:559

*Harms CA, McClellan-Green P, Godfrey MH, Christiansen EF, Broadhurst HJ, Godard-Codding CAJ (2019) Crude oil and dispersant cause acute clinicopathological abnormalities in hatchling loggerhead sea turtles (Caretta caretta). Front Vet Sci 6:344

* Hartig F (2020) DHARMa: residual diagnostics for hierarchical (multi-level/mixed) regression models. $\mathrm{R}$ package version 0.3.0. https://cran.r-project.org/web/packages/ DHARMa/vignettes/DHARMa.html

Henkel JR, Sigel BJ, Taylor CM (2012) Large-scale impacts of the Deepwater Horizon oil spill: Can local disturbance affect distant ecosystems through migratory shorebirds? Bioscience 62:676-685

Hooper MJ, Schmitt CJ (2015) Chemical and biological analyses of nesting sea turtles and their nests in the northern Gulf of Mexico following the Deepwater Horizon oil spill — draft final report. Columbia Environmental Research Center, US Geological Survey, Columbia, MO

Kauritsen AM, Dixon PM, Cacela D, Brost B and others (2017) Impact of the Deepwater Horizon oil spill on loggerhead turtle Caretta caretta nest densities in northwest Florida. Endang Species Res 33:83-93

* Lazell JD Jr (1980) New England waters: critical habitat for marine turtles. Copeia 1980:290-295

KLüdecke D, Makowski D, Waggoner P, Patil I, Ben-Shachar MS (2020) Assessment of regression models performance. R package version 0.5.1. https://cran.r-project.org/ web/packages/performance/index.html

*McDonald TL, Schroeder BA, Stacy BA, Wallace BP and others (2017) Density and exposure of surface-pelagic juvenile sea turtles to Deepwater Horizon oil. Endang Species Res 33:69-82

Milton S, Lutz PL, Shigenaka G (2010) Oil toxicity and impacts on sea turtles. In: Shigenaka G (ed) Oil and sea turtles: biology, planning, and response. NOAA, National Ocean Service, Office of Response and Restoration, Seattle, WA, p 35-47

*Mitra S, Kimmel DG, Snyder J, Scalise K and others (2012) Macondo-1 well oil-derived polycyclic aromatic hydrocarbons in mesozooplankton from the northern Gulf of Mexico. Geophys Res Lett 39:L01605

*Moreno R, Jover L, Diez C, Sardà-Palomera F, Sanpera C (2013) Ten years after the Prestige oil spill: seabird trophic ecology as indicator of long-term effects on the coastal marine ecosystem. PLOS ONE 8:e77360

Morreale SJ, Standora EA (2005) Western North Atlantic waters: crucial developmental habitat for Kemp's ridley and loggerhead sea turtles. Chelonian Conserv Biol 4: 872-882

*Nakagawa S, Schielzeth H (2013) A general and simple method for obtaining $\mathrm{R}^{2}$ from generalized linear mixedeffects models. Methods Ecol Evol 4:133-142

*Nakagawa S, Johnson PCD, Schielzeth H (2017) The coefficient of determination $\mathrm{R}^{2}$ and intra-class correlation coefficient from generalized linear mixed-effects models revisited and explained. $\mathrm{J} R$ Soc Interface 14: 20170213

NMFS (National Marine Fisheries Service) (2011) Binational recovery plan for the Kemp's ridley sea turtle (Lepidochelys kempii), $2^{\text {nd }}$ revision. National Marine Fisheries Service, Silver Spring, MD

* Peterson CH, Rice SD, Short JW, Esler D, Bodkin JL, Ballachey BE, Irons DB (2003) Long-term ecosystem response to the Exxon Valdez oil spill. Science 302:2082-2086

Pritchard PCH, Márquez-Millán R (1973) Kemp's ridley turtle or Atlantic ridley, Lepidochelys kempi. IUCN Monograph Series No. 2. International Union for Conservation of Nature and Natural Resources, Morges

* Putman NF, Abreu-Grobois FA, Iturbe-Darkistade I, Putman EM, Richards PM, Verley P (2015) Deepwater Horizon oil spill impacts on sea turtles could span the Atlantic. Biol Lett 11:20150596

\% Quintana-Rizzo E, Torres JJ, Ross SW, Romero I, Watson K, Goddard E, Hollander D (2015) $\delta^{13} \mathrm{C}$ and $\delta^{15} \mathrm{~N}$ in deepliving fishes and shrimps after the Deepwater Horizon oil spill, Gulf of Mexico. Mar Pollut Bull 94:241-250 
R Core Team (2020) R: a language and environment for statistical computing. R Foundation for Statistical Computing, Vienna

Reich KJ, López-Castro MC, Shaver DJ, Iseton C, Hart KM, Hooper MJ, Schmitt CJ (2017) $\delta^{13} \mathrm{C}$ and $\delta^{15} \mathrm{~N}$ in the endangered Kemp's ridley sea turtle Lepidochelys kempii after the Deepwater Horizon oil spill. Endang Species Res 33:281-289

Rozas LP, Minello TJ, Miles MS (2014) Effect of Deepwater Horizon oil on growth rates of juvenile penaeid shrimps. Estuar Coasts 37:1403-1414

Seney EE, Landry AM Jr (2008) Movements of Kemp's ridley sea turtles nesting on the upper Texas coast: implications for management. Endang Species Res 4:73-84

Shaver DJ, Caillouet CW Jr (2015) Reintroduction of Kemp's ridley (Lepidochelys kempii) sea turtle to Padre Island National Seashore, Texas and its connection to headstarting. Herpetol Conserv Biol 10:378-435

Shaver DJ, Rubio C (2008) Post-nesting movement of wild and head-started Kemp's ridley sea turtles Lepidochelys kempii in the Gulf of Mexico. Endang Species Res 4:43-55

Shaver DJ, Hart KM, Fujisaki I, Rubio C and others (2013) Foraging area fidelity for Kemp's ridleys in the Gulf of Mexico. Ecol Evol 3:2002-2012

Shaver DJ, Hart KM, Fujisaki I, Rubio C and others (2016a) Migratory corridors of adult female Kemp's ridley turtles in the Gulf of Mexico. Biol Conserv 194:158-167

Shaver DJ, Rubio C, Walker JS, George JA and others (2016b) Kemp's ridley sea turtle (Lepidochelys kempii) nesting on the Texas coast: geographic, temporal, and demographic trends through 2014. Gulf Mex Sci 33: 158-178

Shaver DJ, Hart KM, Fujisaki I, Bucklin D and others (2017) Inter-nesting movements and habitat-use of adult female Kemp's ridley turtles in the Gulf of Mexico. PLOS ONE 12:e0174248

Shigenaka G (2010) Oil and sea turtles: biology, planning, and response. NOAA, National Ocean Service, Office of

Editorial responsibility: Bryan P. Wallace,

Fort Collins, Colorado, USA

Reviewed by: 3 anonymous referees
Response and Restoration, Seattle, WA

* Van Meter RJ, Spotila JR, Avery HW (2006) Polycyclic aromatic hydrocarbons affect survival and development of common snapping turtle (Chelydra serpentina) embryos and hatchlings. Environ Pollut 142:466-475

Wallace BP, DiMatteo AD, Hurley BJ, Finkbeiner EM and others (2010) Regional management units for marine turtles: a novel framework for prioritizing conservation and research across multiple scales. PLOS ONE 5: e15465

Wallace BP, Stacy BA, Rissing M, Cacela D and others (2017) Estimating sea turtle exposures to Deepwater Horizon oil. Endang Species Res 33:51-67

* White HK, Hsing PY, Cho W, Shank TM and others (2012) Impact of the Deepwater Horizon oil spill on a deepwater coral community in the Gulf of Mexico. Proc Natl Acad Sci USA 109:20303-20308

Wibbels T, Bevan EM (2016) A historical perspective of the biology and conservation of the Kemp's ridley sea turtle. Gulf Mex Sci 33:129-137

*Wibbels T, Bevan EM (2019) Lepidochelys kempii (errata version published in 2019). The IUCN Red List of Threatened Species 2019:e.T11533A155057916. https://dx.doi.org/10. 2305/IUCN.UK.2019-2.RLTS.T11533A155057916.en

*Wilson RM, Cherrier J, Sarkodee-Adoo J, Bosman S, Mickle A, Chanton JP (2016) Tracing the intrusion of fossil carbon into coastal Louisiana macrofauna using natural ${ }^{14} \mathrm{C}$ and ${ }^{13} \mathrm{C}$ abundances. Deep Sea Res II 129:89-95

Witzell WN, Salgado-Quintero A, Garduño-Dionte M (2005) Reproductive parameters of the Kemp's ridley sea turtle (Lepidochelys kempii) at Rancho Nuevo, Tamaulipas, Mexico. Chelonian Conserv Biol 4:781-787

Zuur AF, Ieno EN, Elphick CS (2010) A protocol for data exploration to avoid common statistical problems. Methods Ecol Evol 1:3-14

Zychowski GV, Godard-Codding CAJ (2017) Reptilian exposure to polycyclic aromatic hydrocarbons and associated effects. Environ Toxicol Chem 36:25-35

Submitted: September 11, 2020

Accepted: December 18, 2020

Proofs received from author(s): March 16, 2021 